\title{
RUGĀCIUNEA PENTRU LUME CA EXPRESIE A VOCATIEI MISIONARE A BISERICII. O ABORDARE DIN PERSPECTIVA TEOLOGIEI SFÂNTULUI SILUAN ŞI A PĂRINTELUI SOFRONIE SAHAROV
}

Florin Botezan

\begin{abstract}
One of the major themes of the theology of Saint Silouan and Father Sophrony is the prayer for the world, a prayer that is understood as an expression of the spiritual condition of man who, through the action of the Holy Spirit, become like Christ Who bears in his heart all the humanity. Each member of the Church, to the extent of his spiritual advance to the image of Christ, get to live more intense the consciousness of the ontological unity of all humankind and pray, in the words of Father Sophrony, for all Adam as for himself. The continuous communion with the Divine Mysteries and the descending of the mind in the heart are conditions for such a prayer for the world. Receiving Christ in the Eucharist, we unite with Him, we become one with Him, we dwell in Him and He dwells in us. On the other hand, when the mind descends in his inmost heart, man finds his deep heart, reaches the profound spiritual, metaphysical core of his being; and looking into it sees that the existence of mankind is not something alien and extraneous to him but is inextricably bound up with his own being. According to Father Sophrony, the highest prayer for the world is liturgical prayer, the most similar human prayer with the prayer of Jesus in Gethsemane. Regarding the mission of the Church, Father Sophrony says that the one who knows by experience the sublimity and the difficulties of the Christian way, prefers to turn to God and pray for the salvation of one and all, rather than preach. This is why St. Silouan writes that the service to the world of the pastors of the Church and monks is praying for the world.
\end{abstract}

* PhD Assistant Professor, "1 Decembrie 1918" University of Alba Iulia (Faculty of Orthodox Theology) and teacher of Homiletics, Catechetics and Orthodox Spirituality at "St. Simion Ştefan" Orthodox Theological Seminary in Alba Iulia, Romania. 
Keywords: Saint Silouan, Father Soprony, prayer for the world, all Adam, prayer of Jesus in Gethsemane

\section{Argument}

În fiecare generație Dumnezeu grăieşte lumii prin aleşii Săi pentru a aprinde în inimile oamenilor credința cea adevărată ,,dată sfinţilor odată pentru totdeauna" (Iuda 1,3). Un mare bărbat sfânt prin care Dumnezeu vesteşte generației noastre căile mântuirii este Cuviosul Siluan Athonitul (1866-1938), al cărui cuvânt plin de putere, însuflat de Duhul Sfânt, a fost făcut cunoscut lumii şi tâlcuit de ucenicul său, Cuviosul Sofronie Saharov (1897-1993).

Ridicându-se el însuşi la măsurile duhovniceşti ale starețului său, Părintele Sofronie a înțeles profunzimea cuvântului Sfântului Siluan şi importanţa lui capitală pentru omul vremurilor noastre, râvnind din toată inima să-1 facă cunoscut tuturor popoarelor pământului. El se face un vestitor atât al teologiei Sfântului Siluan - proslăvit de Biserică în anul 1988 ca „dascăl apostolic şi prorocesc” -, teologie înțeleasă ca descriere a întâlnirii personale cu Hristos, cât şi a propriei sale experiențe a viețuirii cu Dumnezeu şi în Dumnezeu. O astfel de teologie este, după cum subliniază Părintele Sofronie, un har al Duhului Sfânt ce aprinde inima omului, făcând din cel ce a primit acest har o lumină în lume care împărtăşeşte cuvintele vieții.

\section{Rugăciunea pentru lume - dar al Sfântului Duh care ne face asemănători cu Hristos}

Una din temele centrale ale teologiei Sfântului Siluan şi a Părintelui Sofronie o reprezintă rugăciunea pentru lume, rugăciune ce nu este înțeleasă doar ca o datorie a creștinului ci ca o expresie a stării duhovniceşti a omului care, prin lucrarea Duhului Sfânt, devine asemănător cu Hristos, $\mathrm{Cel}$ ce poartă în inima Sa întreaga umanitate. Fiecare mădular al Bisericii, în măsura înaintării sale duhovniceşti spre asemănarea cu Hristos, ajunge să trăiască tot mai intens conştiința unității ontologice a întregii umanități şi să se roage, 
potrivit expresiei Părintelui Sofronie, pentru întreg Adamul $^{1}$ ca pentru sine însuşi. „În Evanghelie este spus limpede, subliniază Sfântul Siluan într-o discuție cu Părintele Sofronie. Când samarinenii nu au voit să-L primească pe Hristos, Apostolii Iacov şi Ioan au voit să aducă foc din cer spre a-i pierde, însă Domnul i-a oprit, zicând: Voi nu ştiți ai cărui duh sunteți. Eu nu am venit să pierd oamenii ci să-i mântuiesc (Lc. 9, 52-56). Și noi datori suntem să avem numai acest gând - ca toți să se mântuiască’’2 .

Rugăciunea desăvârşită pentru întreaga lume este o stare duhovnicească pe care o atinge cel căruia Duhul Sfânt îi dăruiește să trăiască starea lui Hristos şi să iubească întreg neamul omenesc ca pe sine însuşi. Este ceea ce trăit Sfântul Siluan când L-a văzut pe Hristos viu în icoană şi întreaga sa făptură, până şi trupul, i s-a umplut de focul harului Duhului Sfânt, o mare lumină dumnezeiască luminându-l şi primind ca o nouă naştere de sus $^{3}$. Prin lucrarea Duhului Sfânt inima Sfântului Siluan s-a lărgit primindu-i în ea pe toți oamenii, vii şi adormiți, născuți şi nenăscuți, începând să se roage pentru întreg Adamul cu adânc plâns, mai mult decât pentru sine însuşi ${ }^{4}$. Practic, în clipa vederii lui Hristos cel viu, Sfântului Siluan i s-a împărtăşit starea lui Hristos, „Noul Adam”, pentru că Hristos poartă în El întreaga omenire şi Duhul Său vrea ca toți oamenii să se mântuiască. Aceasta este apostoleasca lărgire a inimii (II Cor. 6, 13) şi rugăciunea pentru lume pe care ucenicii lui Hristos o primesc de la Duhul Sfânt: „A se ruga numai pentru sine îi devenise un lucru străin... Sufletul îi era chinuit de conştientizarea că oamenii trăiesc fără să cunoască pe Dumnezeu şi dragostea Sa, şi se ruga din răsputeri ca Domnul, pentru negrăită dragostea $\mathrm{Sa}$, să le dea

${ }^{1}$ Concept specific Părintelui Sofronie, ,întreg Adamul nu este o abstracție, ci deplinătatea cea mai concretă a fiinţării omenești”. Vezi Arhim. Sofronie, Cuviosul Siluan Athonitul, trad. din limba rusă de Ierom. Rafail (Noica), Alba Iulia, Editura Reîntregirea, 2009, p. 242.

${ }^{2}$ Arhim. Sofronie, Cuviosul Siluan Athonitul..., p. 246.

${ }^{3}$ Ibidem, p. 29.

${ }^{4}$ Idem, Cuvântări duhovniceşti, vol. I, trad. din limba rusă de Ierom. Rafail (Noica), Alba Iulia, Editura Reîntregirea, 2004, p. 70. 
a-L cunoaşte"

Covârşitoarea revărsare a harului Duhului Sfânt pe care Sfântul Siluan a trăit-o la începutul viețuirii sale monahale este o experiență de care nu mulți au parte, deoarece Domnul ştie că puțini pot purta greutatea pierderii harului şi a părăsirii de Dumnezeu, care urmează din cauza lipsei de smerenie. Pentru majoritatea oamenilor începutul vieții duhovnicești este reprezentat de o uşoară atingere a harului, ce se poate manifesta în diverse feluri. Cel care înțelege chemarea lui Dumnezeu şi se angajează în efortul ascetic al împlinirii poruncilor dumnezeieşti şi al despătimirii, este învrednicit de cercetări tot mai puternice ale harului care îl conduc spre trăirea stării lui Hristos, spre a nu căuta numai ale sale ci şi ale altora, spre a avea, gândul care era în Hristos Iisus" (Filip. 2, 4-5) şi a ajunge astfel la rugăciunea pentru lume ca pentru sine.

\section{3. Împărtăşirea continuă şi pogorârea minţii în inimă - condiții ale rugăciunii pentru lume}

Locul unde se dă bătălia duhovnicească cu răul şi unde se cultivă împărtăşirea lui Dumnezeu cu omul, unde harul Duhului Sfânt se descoperă şi lucrează, este inima omului, înțeleasă în sens scripturistic ca centrul duhovnicesc al făpturii umane. Dacă egoismul, rădăcina tuturor patimilor, ne desparte de Dumnezeu şi de oameni îngustându-ne inima şi făcându-ne robi diavolului, smerenia cea adevărată câştigată prin ascultarea cuvântului lui Dumnezeu, lepădarea de sine, asumarea crucii şi urmarea lui Hristos (Mc. 8, 34) ne deschide lucrării Duhului Sfânt care ne lărgeşte inima spre a cuprinde toată dragostea faţă de Dumnezeu şi oameni poruncită de Mântuitorul Hristos. Ajungem astfel la acea stare atât de frumos exprimată de cuvântul românesc mărinimie - inima mare, inima lărgită de Duhul Sfânt care îl cuprinde în ea pe Dumnezeu şi întreaga umanitate.

Eliberarea de patimi şi de robia faţă de diavol, lărgirea inimii şi

${ }^{5}$ Arhim. Sofronie, Cuviosul Siluan Athonitul .., p. 54. 
înaintarea omului spre asemănarea cu Dumnezeu, se întemeiază pe unirea cu Hristos prin Sfintele Taine şi reprezintă rodirea Botezului, Mirungerii şi Euharistiei în inimă. Mărturia părinților filocalici ne încredințează că, după naşterea din nou din apă şi din Duh, nimic nu contribuie atât de mult la curăţirea inimii şi la luminarea minții, la biruirea patimilor şi a demonilor şi la unirea cu Dumnezeu cea mai presus de fire, ca împărtăşirea continuă cu Trupul şi Sângele Domnului ${ }^{6}$. Euharistia desăvârşeşte celelalte Taine şi împlineşte îndumnezeirea personală a oamenilor deoarece devenim una cu Hristos, ne sălăşluim în El şi El în noi. Cuminecându-ne cu Trupul şi Sângele Domnului Îl primim pe Hristos întreg nu numai în trupul nostru ci şi în sufletul nostru. „Trupul şi Sângele lui Hristos intră în alcătuirea (în constituția) sufletului şi trupului nostru, arată Sfântul Ioan Damaschin, netopindu-se, nestricându-se, netrecând în ceea ce dăm afară, ci rămânând în ființa noastră, ca pricină a păstrării noastre, ca mijloc de curăţire a toată întinăciunea"7.

Trupul lui Hristos este atât de intim pătruns de Duhul Sfânt încât împărtăşirea cu Hristos înseamnă şi împărtăşirea cu Sfântul Duh. Prin mâncarea Trupului şi Sângelui lui Hristos nesfârşit înduhovnicite şi, deci, inseparabile de plinătatea Duhului Sfânt, ne hrănim şi înduhovnicim trupul şi sufletul, Duhul dumnezeiesc întărind sufletul nostru în biruirea proceselor nelibere ale naturii trupului nostru şi unificând făptura noastră cu Dumnezeu ${ }^{8}$. Împărtăşindu-ne cu Hristos ne unim cu El şi primim puterea de a ne angaja cu dragoste în nevoința împlinirii voii lui Dumnezeu, în nevoința împlinirii poruncii iubirii concretizată în rugăciunea pentru

${ }^{6}$ Calist și Ignatie Xanthopol, Metoda sau cele 100 de capete, 91 , în „Filocalia”, vol. VIII, trad., introd. şi note de Pr. Prof. Dr. Dumitru Stăniloae, București, Editura IBMBOR, 1979, p. 201.

7 Sfântul Ioan Damaschin, De fide orthodoxa, IV, XIII, PG 94, 1117-1148, apud Cele 100 de capete ale lui Calist şi Ignatie Xanthopol, 92, în .,Filocalia”. vol. VIII, trad., introd. şi note de Pr. Prof. Dr. Dumitru Stăniloae, Bucureşti, Editura IBMBOR, 1979, p. 205.

8 Dumitru Stăniloae, Liturghia comunității şi jertfa interioară în viziunea filocalică, în „Ortodoxia”, an XXX, nr 1-2, 1978, p. 393. 
lume. Fiecare cuminecare înseamnă hrănire cu Trupul şi Sângele de viață făcător al lui Hristos cel înviat, Trupul împreună cu Sufletul şi cu Dumnezeirea Lui, Trupul Său plin de Duhul Sfânt, înseamnă un plus de putere în nevoinţa noastră duhovnicească şi o părtăşie, prin lărgirea inimii, la starea lui Hristos Care îmbrățişează cu dragoste întreaga umanitate. „Energiile dumnezeieşti ale lui Hristos şi, deci, Hristos Însuşi, remarcă Părintele Stăniloae, îşi prelungesc lucrarea în noi, dar ele pornesc din Trupul Lui şi de aceea e nevoie să primim cât mai des acest Trup"".

Pentru ca Hristos primit în Sfânta Euharistie să-şi împlinească în noi lucrarea Sa curățitoare, luminătoare şi îndumnezeitoare este esenţial ca omul să se străduiască să-şi păzească mintea de gânduri rele şi, adunându-o din împrăştiere, să şi-o îndrepte spre inimă. De altfel împărtăşania însăşi este ajutorul decisiv în nevoința trezviei minții şi a pogorârii ei în inimă:

„Când ne învrednicim nevrednicii, cu frică şi cu cutremur de dumnezeieştile şi preacuratele Taine ale lui Hristos, Dumnezeul și Împăratul nostru, atunci şi mai mult să arătăm trezvia, păzirea minţii și osârdia, ca focul cel dumnezeiesc sau Trupul Domnului nostru Iisus Hristos să mistuie păcatele noastre şi necurăţiile mici şi mari. Căci intrând în noi, El alungă îndată din inimă duhurile viclene ale răutăţii și ne iartă păcatele făcute mai înainte, și atunci mintea rămâne fără tulburarea gândurilor rele. Şi dacă după aceea ne vom păzi cu osârdie mintea şi vom sta în poarta inimii noastre, când ne vom învrednici iarăşi de ele, Dumnezeiescul Trup ne va lumina și mai mult mintea şi o va face asemenea unei stele."10

Păcatul şi patimile au produs o sfâşiere în fiinţa omului făcând ca mintea să se despartă de inimă şi să fie îndreptată în afară, devenind pradă gândurilor de tot felul care ne împrăştie. Ca urmare efortul ascetic al omului, suștinut de împărtăşirea continuă cu Sfintele Taine, trebuie concentrat spre pogorârea minții în inimă prin

${ }^{9}$ Ibidem, p. 395.

${ }^{10}$ Isihie Sinaitul, Scurt cuvânt de folos sufletului şi mântuitor despre trezvie şi virtute, Suta întâia, 100, p.66. 
rugăciune şi îndreptarea cu toată fiinţa spre Dumnezeu. Întreaga nevoință a rugăciunii are ca scop tocmai descoperirea şi cucerirea inimii. Deschiderea inimii prin rugăciune vindecă persoana omului. Mintea omului se adună înlăuntru şi se uneşte cu inima şi astfel inima se lărgeşte spre a cuprinde toată plinătatea dragostei lui Hristos $^{11}$.

Pogorându-se cu mintea în inimă, omul îşi află inima adâncă, duhovnicească, metafizică, şi în ea vede că ființarea întregii omeniri nu îi este ceva străin, exterior, ci este nedespărțit legată de propria ființare. Ca urmare începe să înțeleagă că în porunca de a-ți iubi aproapele ca pe tine însuți, cuvântul „ca" nu arată măsura iubirii ci părtăşia ontologică a ființăriii ${ }^{12}$.

„Mi s-a dat să înțeleg, mărturisește Părintele Sofronie spre sfârşitul vieții sale, această poruncă (a iubirii aproapelui ca pe tine însuți) în chipul unui arbore cosmic, uriaş, a cărui rădăcină este Adam. Eu nu sunt decât o mică frunză pe un ram al acestui arbore. Însă arborele nu-mi este străin: este temeiul meu. Îi aparțin. A te ruga pentru lumea întreagă este a te ruga pentru acest arbore în întregul său, cu toate miliardele sale de frunze. A urma lui Hristos este a te deschide cugetului lui Hristos Însuși, ce poartă în sine omenirea întreagă, întreg arborele, fără a lăsa la o parte o singură frunză. Dacă dobândim această conștiință ne vom ruga pentru toți ca pentru noi înșine."”3

\section{Rugăciunea lui lisus şi rugăciunea pentru lume}

Cel mai la îndemână mijloc pentru coborârea minții în inimă şi îndreptarea spre Dumnezeu este chemarea continuă a numelui

11 Arhim. Zaharia (Zaharou), Lărgiți şi voi inimile voastre (II Cor. 6, 13). Lărgirea inimii în teologia Sfântului Siluan Athonitul şi a Starețului Sofronie de la Essex, trad. din limba engleză de monahia Mariam Vicol în colaborare cu monahiile Tecla şi Fevronia de la Essex, Alba Iulia, Editura Reîntregirea, 2009, p. 151.

${ }_{12}$ Arhim. Sofronie, Cuviosul Siluan Athonitul.., p. 52.

${ }^{13}$ Idem, Din Viaţă şi din Duh, trad. din limba franceză de Ierom. Rafail (Noica), Alba Iulia, Editura Reîntregirea, 2011, p. 21. 
Domnului, în cuvinte simple şi puține, prin rostirea Rugăciunii lui Iisus: „Doamne Iisuse Hristoase, Fiul lui Dumnezeu, miluieşte-mă pe mine păcătosul!” sau, mai simplu, „Doamne Iisuse Hristoase, miluieşte-mă!".

Rostind neîncetat Rugăciunea lui Iisus, credinciosul se împărtăşeşte necontenit cu energia necreată a harului lui Hristos şi trăieşte nespusa desfătare ce vine de la Duhul Sfânt, devine părtaş la universalitatea Noului Adam şi aduce înaintea lui Dumnezeu întreaga zidire ca un adevărat preot al creației. De aceea Rugăciunea lui Iisus este cea mai potrivită pregătire pentru dobândirea rugăciunii pentru lume ${ }^{14}$.

Chiar mai mult, pentru cel care, prin pogorârea minții în inimă, înțelege în mod existențial părtăşia ființială a întregii umanități, rugăciunea „Doamne, Iisuse Hristoase, miluieşte-mă!” nu mai este o rugăciune pentru sine, ci devine o rugăciune pentru întreg Adamul. Este felul în care se ruga Sfântul Porfirie Kavsokalivitul pentru cei care îi cereau rugăciunea, răspunzând celui care îşi exprima uimirea cum se poate ruga pentru altcineva spunând „miluiește-mă”: „Nu ştii că tu şi eu una suntem?"15. Este rugăciunea bătrânului monah athonit întâlnit de Părintele Sofronie la începutul călugăriei sale şi care, atunci când Părintele Sofronie îi cere să se roage pentru el, îi explică cu blândețe că el este cuprins deja în rugăciunea sa: „Mă rog pentru lumea întreagă; tu eşti acolo, ca noi să nu ne rupem în bucățele pentru amănunte"16.

Atunci când a înființat Mănăstirea Sfântului Ioan Botezătorul de la Essex, neavând posibilitatea săvârşirii slujbelor Laudelor potrivit tipicului, Părintele Sofronie a optat pentru rostirea în comun a unei formule adaptate a Rugăciunii lui Iisus, care să-i ajute şi pe cei nedesăvârşiți să se roage pentru comunitate şi pentru întreaga lume: „Doamne, Iisuse Hristoase, miluieşte-ne pe noi şi lumea Ta!", formulă de rugăciune care poate fi folosită de tot cel care nu ajuns

${ }^{14}$ Arhim. Zaharia, Lărgiți şi voi inimile voastre..., p. 185.

${ }^{15}$ Părintele Porfirie, Antologie de sfaturi şi indrumări, trad. din limba greacă de Sorina Munteanu, Bacău, Editura Bunavestire, s.a., p. 354.

${ }^{16}$ Arhim. Sofronie, Cuvântări duhovniceşti .., vol. I, p. 322. 
încă la o atât de adâncă înțelegere a unității ființiale a umanității încât să trăiască formula clasică a Rugăciunii lui Iisus ca o rugăciune pentru întreg Adamul.

\section{Rugăciunea liturgică - cea mai înaltă rugăciune a omului pentru lume}

Isihia, petrecerea neîncetată în Dumnezeu cu mintea adunată în inimă, adică „intrarea înlăuntru şi aflarea odihnei”"17, este starea spre care trebuie să tindă tot creştinul, atât călugărul cât şi mireanul. Părintele Sofronie, alături de alți mari părinți duhovniceşti contemporani, remarca însă că omul de azi, mai ales cel ce trăieşte în lume, este mult mai puțin capabil şi dispus pentru isihie decât cei vechi, deoarece nu-şi mai poate țintui mintea într-un loc. Supusă la o mulțime de stimuli, mintea fuge şi se împrăştie şi omul nu mai poate dobândi o asemenea rugăciune a minții cum citim la Sfinții Părinţi. Totuşi, dacă slujim Liturghia cum se cuvine, la nivelul rugăciunii vom avea aceleaşi roade ca şi părinții care se rugau liniştindu-se în pustie $^{18}$.

„Observațiile mele asupra oamenilor contemporani, scrie Părintele Sofronie, m-au dus la concluzia că cel mai potrivit lucru pentru ei este să se roage în biserici, în special la Sfânta Liturghie. Rugăciunea liturgică şi o deasă împărtăşanie înseamnă plinătate. Pentru aceasta trebuie însă să trăim și să înțelegem Sfânta Liturghie. Atunci ni se va descoperi că Liturghia îmbrățișează în sine întreaga noastră viață; în ea se cuprind toate planurile existenței noastre în relație cu Dumnezeu... Fără să aprofundeze cunoștințele sale în acest domeniu omul poate cădea uşor într-un obicei pustiitor şi aducător de moarte. Este nevoie să creștem neîncetat în cunoașterea

17 Părintele Zaharia de la Mănăstirea Sfântul Ioan Botezătorul din Essex, consideră că această expresie cuprinde în sine întreaga tradiție şi teologie a isihasmului. Vezi Arhimandritul Zaharia Zaharou, Omul cel tainic al inimii (I Petru 3, 4), trad. de Monahia Tecla, București, Editura Basilica, 2014, p. 187.

18 Arhim. Sofronie, Cuvântări duhovniceşti, vol. I, p. 324; Arhim. Zaharia, Lărgiți şi voi inimile voastre, p. 165. 
lui Dumnezeu şi să nu permitem ca Liturghia să se transforme întrun detaliu al vieții noastre de toate zilele."

Părintele Sofronie arată că Dumnezeiasca Liturghie este cea mai înaltă rugăciune a omului pentru lume, ea exprimând cel mai îndeaproape rugăciunea ipostatică, adică rugăciunea asemănătoare celei a lui Hristos din Ghetsimani. Dar „trec nu puțini ani până să ajungem la măsura de a ne adânci în duhul adevăratelor dimensiuni ale Liturghiei" $"$.

Rugăciunea Mântuitorului din Ghetsimani, subliniază Părintele Sofronie $^{21}$, este cea mai înaltă dintre toate rugăciunile, atât după vrednicia sa lăuntrică cât şi după puterea sa răscumpărătoare a lumii. În noaptea arestării Sale, Domnul Hristos S-a rugat cu atâta intensitate pentru suferința întregii lumi, încât sudoarea Sa s-a preschimbat în sânge. În această rugăciune Domnul a cuprins tot ceea ce s-a întâmplat din clipa ivirii în viață a întâiului Adam şi până la ultimul om ce se va naşte din femeie. Deşi ca fapt istoric n-a durat mult, ca act duhovnicesc al dragostei lui Dumnezeu ea a început mai înainte de întemeierea lumii şi nu încetează până în ziua de azi. Prezența ei o simţim atunci când încercăm şi noi să ne rugăm pentru lumea întreagă şi, mai ales, la Dumnezeiasca Liturghie.

Actul liturgic ne formează spre a petrece în atmosfera lui Hristos, spre a îmbrățişa în duh întreaga lume, cu toate suferințele ei ${ }^{22}$. Sensibilitatea duhovnicească a Părintelui Sofronie 1-a ajutat să înţeleagă şi să ne transmită şi nouă că rugăciunea liturgică este una dintre cele mai grele pentru că se trăieşte deplin într-o cumplită sfâşiere a întregii noastre ființe, într-o necontenită mişcare când către Dumnezeu, când către lume ${ }^{23}$. Atât preotul cât şi credincioşii care

${ }^{19}$ Ne vorbeşte Părintele Sofronie. Scrisori, trad. de Pr. Prof. Teoctist Caia, Galați, Editura Bunavestire, 2003, p. 71.

${ }^{20}$ Arhim. Sofronie, Vom vedea pe Dumnezeu precum este, trad. din limba rusă de Ierom. Rafail (Noica), București, Editura Sophia, 2005, p. 323.

${ }^{21}$ Ibidem, p. 349.

${ }^{22}$ Ibidem, p. 334.

${ }^{23}$ Ibidem. 
participă la Dumnezeiasca Liturghie se învață, după pilda lui Hristos Insuşi, a trăi în două planuri: a petrece în duh în tărâmul dumnezeiesc şi, totodată, a se face îndeaproape împreună-părtaşi în destinele tragice ale lumii ${ }^{24}$. Prin Liturghie cunoaştem taina cea din veac ascunsă a răstignirii dragostei lui Dumnezeu dar şi îmbrăţişăm în rugăciune întreaga lume cu toate durerile sale.

Încă de la începutul Dumnezeieştii Liturghii, ectenia mare este o rugăciune care îmbrățişează întreaga lume, o primă părtăşie la rugăciunea lui Hristos din Ghetsimani, pentru ca, mai apoi, ectenia întreită să fie o aplecare asupra nevoilor particulare ale omului arătând valoarea unică a fiecărei persoane. Dar, mai presus de toate, rugăciunea centrală a Dumnezeieştii Liturghii, anaforaua, rostită de către protos în numele întregii Biserici, exprimă dialogul făpturii, al întregului Adam, cu Creatorul Său, o regăsire a vocației originare a omului de a-I mulțumi lui Dumnezeu şi de a I se închina Lui în Duh şi adevăr, dar şi părtăşie la rugăciunea lui Hristos pentru lume din Ghetsimani, asumând durerea întregii umanități ca durere proprie. Apoi, la momentul culminat al Dumnezeieştii Liturghii, prin împărtăşirea celor prezenți „Hristos Îşi adună pe cei dăruiți Lui în acea unime dată nouă drept sarcină de către Făcătorul nostru: zidiți după „chip şi asemănare” - suntem chemați la unire după chipul Sfintei Treimi" 25

Părintele Sofronie obişnuia să rostească cu voce tare, rar şi apăsat, anaforaua liturgică deoarece era convins că „neapărat este ca fiecare dintre noi să ne adâncim astfel în Liturghie, pentru ca vecinica ei realitate să ne însoțească în viața de zi cu zi; pentru ca rugăciunea preoțească să devină firea noastră, pentru ca adevărat să ne facem împărați şi preoți lui Dumnezeu" ${ }^{\text {26. }}$.

Esența lăuntrică a preoției împărăteşti (I Pt. 2, 5), care este cu putință şi fără a purta cinul preoției, constă tocmai în faptul de a se ruga pentru întreaga lume potrivit pildei Mântuitorului. „Ultima

\footnotetext{
${ }^{24}$ Ibidem, p. 337.

${ }^{25}$ Ibidem, p. 340.

${ }^{26}$ Ibidem, p. 337.
} 
măsură la care putem ajunge este a ne ruga pentru întreg Adamul ca însuşi pentru sine. $O$ astfel de rugăciune este semnul că în noi se rezideşte acel „chip" întru care a fost zidit omul (Fac 1, 26). Suferințele lui Hristos învierea Sa au câştigat omenirii acest har (Lc 24, 46-49). Toți şi fiecare dintre cei ce cred în Fiul lui Dumnezeu sunt chemați spre a primi acest dar de la Dătătorul darurilor: a fi „preoție împărătească”. Nu este preț acestei binecuvântări, însă ea se agoniseşte printr-o lungă şi dureroasă nevoință"27.

\section{Rugăciunea pentru lume ca expresie a vocației misionare a Bisericii}

Mântuitorul Iisus Hristos ,voieşte ca toți oamenii să se mântuiască şi la cunoştința adevărului să vină” (I Tim. 2, 4), de aceea Biserica, trupul tainic al lui Hristos extins în umanitate, are misiunea de a vesti adevărul, de a chema continuu tot omul la a primi prin credință viața veşnică şi de a îmbrățişa întreaga lume cu o rugăciune izvorâtă din dragostea care voieşte ca nimeni să nu piară. Părintele Sofronie afirmă că cel ce a cunoscut din cercare măreția şi greutatea căii creştine „,̂ntr-o mai mare măsură se îndreptează către Dumnezeu cu rugăciunea pentru mântuirea tuturor şi a fieştecăruia, decât către propoveduire. Adevăratul creștinism aproape că nu se propoveduieşte în lume, căci această propoveduire depăşeşte puterile omului" 28. De aceea Sfântul Siluan arată că principala lucrare a monahilor şi a păstorilor Bisericii trebuie să fie rugăciunea pentru lume:

„Monahul este un rugător pentru întreaga lume; el plânge pentru întreaga lume, şi aceasta este lucrarea lui de căpetenie. Cine îl îndeamnă să plângă pentru întreaga lume? Îl îndeamnă Domnul Iisus Hristos, Fiul lui Dumnezeu. El dă monahului dragostea Sfântului Duh, şi din această dragoste inima monahului necontenit

${ }^{27}$ Ibidem, p. 343.

${ }^{28}$ Arhim. Sofronie, Cuviosul Siluan Athonitul.., p. 239. 
se întristează pentru norod, că nu toți se mântuiesc. Însuși Domnul într-atâta Se întrista pentru norod, că S-au dat pe Sine morții pe cruce. Și Maica Domnului aceeași durere pentru toți oamenii purta în inima ei. Și ea, asemenea Fiului său iubit, tuturor până la sfârşit le dorea mântuirea.

Pe acelaşi Duh Sfânt L-au dat Domnul Apostolilor și Sfinţilor noştri Părinți, şi păstorilor Bisericii. În aceasta stă slujirea noastră lumii, şi de aceea nici păstorii Bisericii, nici monahii nu trebuie să se îndeletnicească cu lucruri lumești, ci să urmeze Maicii Domnului, Carea în Biserică, în Sfânta sfintelor, zi și noapte se învăța în legea Domnului şi petrecea în rugăciune pentru norod."29

Părintele Sofronie îşi învăța obştea de la Essex că, în nevoinţa lărgirii inimii până la a ajunge la universalitatea lui Hristos, este foarte important ca fiecare monah să poarte în inima sa pe toți frații din obşte, pentru că astfel va ajunge să poarte în inima sa întreaga $\operatorname{lume}^{30}$. La fel, preotul este dator să-i poarte în inimă pe toți enoriaşii şi fiii săi duhovniceşti.

Rugăciunea pentru lume nu este însă doar o datorie a monahilor şi a păstorilor Bisericii. Toți membri Bisericii sunt chemați să-şi asume preoția împărătească şi să se roage pentru lume. Astfel mirenii pot începe prin purtarea în inimă a celor din familie, a prietenilor şi a celorlalți membri ai parohiei, străduindu-se să lărgească tot mai mult cercul până la a-i cuprinde şi pe vrăjmaşi. De asemenea suntem datori cu toții să ne rugăm pentru cei care ne cer aceasta şi pentru toți cei aflați în suferință. Sfântul Paisie Aghioritul, ca de altfel şi Sfântul Siluan şi Părintele Sofronie, subliniază faptul că rugăciunea trebuie făcută cu durere şi că trebuie să învățăm ca, de la cazurile concrete, să trecem la rugăciunea generală pentru toți cei aflați în suferință şi nevoi şi pentru toți cei adormiți ${ }^{31}$.

O inițiativă recentă, pornită de la o comunitate românească din

${ }^{29}$ Ibidem, p. 433.

${ }^{30}$ Arhim. Zaharia, Lărgiți și voi inimile voastre ..., p. 221.

${ }^{31}$ Vezi Cuviosul Paisie Aghioritul, Trezire duhovnicească, trad. din limba elenă de Ieroschim. Ștefan Lacoschitiotul, Schitul Lacu, Sfântul Munte Athos, 2000, pp. 299-318. 
diaspora, exprimă foarte bine împlinirea vocației misionare a Bisericii prin rugăciune, chemând creştinii din parohii să se organizeze în grupuri care să facă o rugăciune de noapte în chipul unei candele întreținute prin participarea tuturor. După modelul mărturisitorilor din închisorile comuniste, fiecare este îndemnat să se roage câte o oră pe parcursul nopțiii, dând ,ştafeta" rugăciunii de la unul la altul, astfel încât rugăciunea să curgă neîncetat de-a lungul întregii nopți. Este un cadru ce îl ajută pe omul neputincios de azi de a se ține de o rânduială de rugăciune pentru ceilalți membri ai comunităţii dar şi pentru întreaga lume, întemeindu-se tocmai pe învățătura Părintelui Sofronie despre rugăciunea pentru lume: „Această rugăciune aduce, in timp, o mare apropiere între cei care participă la ea, un fel de «închegare» duhovnicească. Este o jertfă pe care o face fiecare dintre noi, însă harul pe care îl primeşte cel ce se roagă se transmite întregii comunități care participă la această lucrare. De altfel, rugăciunea unora pentru alții este mijlocul cel mai important pentru a ne apropia de frații şi surorile dintr-o parohie/comunitate. Marele Cuvios Sofronie de la Essex ne recomandă să ne rugăm mereu unii pentru alții, ne recomandă să ne purtăm in inimi pe fraţii noştri duhovniceşti, insistând asupra faptului că împreună devenim mai puternici in Duh şi în duh. Căci, zice Starețul de la Essex, când două sau mai multe persoane se unesc în acelaşi scop duhovnicesc, puterea fiecăruia e multiplicată la infinit"32.

\section{Rugăciunea pentru lume a Sfântului Siluan Athonitul}

„Doamne, îndreptează-ne precum o mamă duioasă îşi îndreptează copiii săi mici. Dă fiecărui suflet să cunoască bucuria mântuirii Tale şi puterea ajutorului Tău. Dă uşurare sufletelor chinuite ale poporului Tău şi pe noi pe toți ne învață, prin Duhul Sfânt, să Te cunoaştem pe Tine. Se chinuieşte sufletul omenesc pe pământ, Doamne, şi nu poate să se întărească cu mintea întru Tine, pentru că nu Te cunoaşte pe

${ }^{32} \mathrm{http}: / / \mathrm{www}$. candelar.ro/ accesat la 28.04.15 
Tine, nici bunătatea ta. Mintea noastră este întunecată de grijile lumeşti şi nu putem pricepe plinătatea dragostei Tale. Tu ne luminează. Milostivirii Tale toate îi sunt cu putință. Tu ai spus în Sfânta Evanghelie, că morții vor auzi glasul Fiului lui Dumnezeu şi vor învia. Aşa fă acum: ca sufletele noastre moarte să audă glasul Tău şi să învie, întru bucurie. Amin."”33

\section{Bibliografie}

1. Biblia sau Sfânta Scriptură, Tipărită sub îndrumarea şi cu purtarea de grijă a Prea Fericitului Părinte Teoctist Patriarhul Bisericii Ortodoxe Române, $\mathrm{Cu}$ aprobarea Sfântului Sinod, Bucureşti, Editura Institutului Biblic şi de Misiune al Bisericii Ortodoxe Române, 2002.

2. *** Carte de rugăciuni pentru trebuințele şi folosul creștinului ortodox, tipărită cu binecuvântarea IPS Andrei, Mitropolitul Clujului, Maramureşului şi Sălajului, Cluj Napoca, 2012.

3. *** Ne vorbeşte Părintele Sofronie. Scrisori, trad. de Pr. Prof. Teoctist Caia, Galaţi, Editura Bunavestire, 2003.

4. Arhim. Sofronie, Cuvântări duhovnicești, vol. I, trad. din limba rusă de Ierom. Rafail (Noica), Alba Iulia, Editura Reîntregirea, 2004.

5. Idem, Cuviosul Siluan Athonitul, trad. din limba rusă de Ierom. Rafail (Noica), Alba Iulia, Editura Reîntregirea, 2009.

6. Idem, Din Viață şi din Duh, trad. din limba franceză de Ierom. Rafail (Noica), Alba Iulia, Editura Reîntregirea, 2011.

7. Idem, Vom vedea pe Dumnezeu precum este, trad. din limba rusă de Ierom. Rafail (Noica), Bucureşti, Editura Sophia, 2005.

8. Arhim. Zaharia (Zaharou), Lărgiți şi voi inimile voastre (II Cor. 6, 13). Lărgirea inimii în teologia Sfântului Siluan Athonitul şi a Staretului Sofronie de la Essex, trad. din limba engleză de monahia Mariam Vicol în colaborare cu monahiile Tecla şi Fevronia de la Essex, Alba Iulia, Editura Reîntregirea, 2009. 9. Idem, Omul cel tainic al inimii (I Petru 3, 4), trad. de Monahia Tecla, București, Editura Basilica, 2014.

${ }^{33}$ Carte de rugăciuni pentru trebuințele şi folosul creştinului ortodox, tipărită cu binecuvântarea IPS Andrei, Mitropolitul Clujului, Maramureșului și Sălajului, Cluj Napoca, 2012, p. 94. 
10. Calist şi Ignatie Xanthopol, Metoda sau cele 100 de capete, 91, în „Filocalia”, vol. VIII, trad., introd. şi note de Pr. Prof. Dr. Dumitru Stăniloae, București, Editura IBMBOR, 1979.

11. Cuviosul Paisie Aghioritul, Trezire duhovnicească, trad. din limba elenă de Ieroschim. Ștefan Lacoschitiotul, Schitul Lacu, Sfântul Munte Athos, 2000.

12. Părintele Porfirie, Antologie de sfaturi şi îndrumări, trad. din limba greacă de Sorina Munteanu, Bacău, Editura Bunavestire, s.a.

13. Stăniloae, Dumitru, Liturghia comunitătii şi jertfa interioară în viziunea filocalică în „Ortodoxia”, an XXX, nr 1-2, 1978. 